\title{
Moving Beyond the Question of Education or Exploitation: The Dynamic Experiences of Black Male Student-Athletes
}

\author{
Jonathan Howe ${ }^{1}$ and Marc Johnston-Guerrero ${ }^{2}$ \\ ${ }^{1}$ Temple University, ${ }^{2}$ The Ohio State University
}

\begin{abstract}
Discussions of the Black male student-athlete (BMSA) experience within institutions of higher education tend to be situated in two perspectives. Dominant perspectives argue that BMSAs are being educated while another more critical viewpoint argues that this population is being exploited. This article moves beyond the question of whether BMSAs are being educated or exploited to argue that both can happen. Utilizing critical race theory, we analyze literature on BMSAs to highlight dominant perspectives juxtaposed against more critical views of environmental influences on their experiences. The article then presents a composite counterstory that portrays the notion that this population can experience education and exploitation, as told through the lens of a Black male athlete support professional. We conclude by offering a discussion about approaches that institutions and athletic departments can take to better serve BMSAs, including adopting Cooper's (2016a) Excellence Beyond Athletics framework.
\end{abstract}

Keywords: Black, Student-athlete, Education, Exploitation, CRT

The National Collegiate Athletic Association (NCAA), the governing body that oversees most athletic competition at the collegiate level, is an organization generating hundreds of millions in revenue yearly, surpassing the one billion dollar mark (Hawkins, 2010). Particularly for Division I athletics, not only does the NCAA make a significant amount of money, so too do the individual athletic departments that operate under the NCAA. The bulk of the money generated to run the NCAA and athletic departments comes from a handful of revenue-generating sports (e.g., football and men's basketball), represented primarily by Black ${ }^{1}$ male student-athletes (BMSA; Lapchick et al., 2021). Therefore, institutions (NCAA, athletic departments, and colleges/universities) benefit substantially from the work of Black male bodies, as football and men's basketball bring in the most money (Hawkins, 2010). The question remains: how are BMSAs benefiting from participation? Although scholars, such as Singer $(2008,2019)$ and Cooper (2019), have moved toward answering this 
question, the current manuscript builds on their work to provide further nuance and provide additional ways forward.

At the heart of this question is whether BMSAs are primarily being educated or exploited. Although most simply define education as degree attainment, we adopt a definition from Singer (2019) whereby education consists of the accumulation of knowledge on topics and how to use this knowledge as tools to solve problems, critical thinking ability to navigate a Eurocentric society, and gaining consciousness of oneself in relation to larger society. When considering exploitation, we adopt the moral argument that exploitation at its basic level is the unfair exchange between multiple parties (Van Rheenen, 2013).

The NCAA boasts that at the Division I level, student-athletes graduate at a rate that is higher than the rate of non-student athletes (NCAA, 2020b). However, this does not account for graduation differences between athletes grouped by race, where there is a persistent gap between Black and white student-athletes. Lapchick et al. (2019) noted that Black football players among bowl-eligible schools at the Division I level had a Graduation Success Rate (GSR) of approximately 74\% while their white counterparts had a GSR of $89 \%$ (Lapchick et al., 2019). With the GSR tracking graduation rates of student-athletes over a six-year period (NCAA, 2019), this statement holds that $74 \%$ of Black football players graduated within the six years the NCAA tracks. Though reasons for this graduation gap are varied, clearly Black football players are not being educated to the same extent as white football players, bolstering the claim that BMSAs are being exploited more than educated. Education is more than graduating (Edwards, 1984; Singer, 2019); however, receiving a degree is socially associated with education and provides the athletes with a form of capital that often leads to upward social mobility.

Scholars have argued that the exploitation of BMSAs occurs since they suffer a loss of autonomy while subsequently being used athletically for the school's benefit (Hawkins, 2010). Donnor (2005) emphasized that BMSAs "may be exploited for their athletic ability within the context of education. Usage of the term exploited is appropriate considering the fact that these young men are recruited and admitted to these institutions primarily because of their physical talent" (p. 48). Donnor (2005) continued by proclaiming,

While a Black male football student athlete may be interested in receiving a college education and graduation (or playing professional football), other educational stakeholders such as football coaches and institutions of higher education may be more interested in the personal (i.e., cash bonuses for meeting academic incentives) and institutional advancement gained through association with or exploitation of the physical talents of these student-athletes. (p. 48)

This conceptual paper builds upon Donnor's arguments by reviewing the literature on BMSAs to highlight their challenges at historically white institutions (HWIs) with a focus on better understanding the question of whether they are primarily being educated or exploited. Additionally, this paper aims to provide the necessary answers so that institutions of higher education and athletic departments can improve the 
experiences of these athletes and show they are valued for more than their athletic abilities. To achieve this goal, we utilize critical race theory (CRT) to conceptualize the current literature on BMSAs, challenge dominant narratives, and provide an avenue for a dynamic both/and perspective in relation to the question of education or exploitation.

Given one central tenet of CRT is the use of counterstories to highlight experiential knowledge and disrupt the master/dominant narrative (Delgado \& Stefancic, 2017), we first present the dominant narrative on BMSAs, which suggests that they are primarily being educated. Then we highlight how CRT offers a different perspective on BMSAs as being exploited. We end by offering a composite counterstory based on the literature and experiential knowledge to present a third, dynamic, perspective that highlights that BMSAs can be both educated and exploited and the potential utility of Cooper's (2016a) Excellence Beyond Athletics (EBA) Framework. Utilizing this both/and perspective and the EBA approach, we conclude by offering recommendations to enhance the BMSA experience at HWIs.

\section{Theoretical Framework - Critical Race Theory}

We utilize CRT as a theoretical framework and an analytical tool guiding our scholarly arguments based on the literature regarding BMSAs. Employing CRT allows scholars to critically examine hegemonic powers such as collegiate athletic departments and institutions of higher education and how they perpetuate the status quo power structures that work against Black student-athletes. Gaston-Gayles et al. (2018) highlighted the importance of analyzing information from this lens by positing,

Critical perspectives are necessary to deconstruct academic and athletic capitalism because these systems and structures are rooted in power and privilege and are oppressive to vulnerable populations, in part because generating revenue is prioritized over the educational mission of teaching and learning (p. 14).

These power structures created the inequity within higher education and collegiate athletics, where there has been little change to that status quo. Thus, we utilize CRT to work toward dismantling those inherent ideologies that maintain racial inequities.

Scholars in critical legal studies birthed CRT, which has evolved across various fields, including education (Ladson-Billings, 2013). One of the most prominent figures of CRT, Derrick Bell, emphasized that CRT's "commitment to anti-racism goes well beyond civil rights, integration, affirmative action, and other liberal measures" (Bell, 1995, p. 899). Additionally, CRT provided an avenue to utilize techniques and express certain viewpoints that previous theories and fields of study failed to offer (Bell, 1995). Delgado and Stefancic (2017) outline several tenets when discussing CRT in the legal realm: belief that racism is normal and ordinary, interest convergence/material determinism, the social construction of race, intersectionality/ anti-essentialism, and the importance of voice and the counternarrative. These tenets are related to those traditionally used in the field of higher education.

Within higher education, Solórzano and Yosso (2002) champion the usage of CRT and outline the following CRT tenets: the intercentricity of race and racism 
with other forms of subordination, the challenge to the dominant ideology, a commitment to social justice, the centrality of experiential knowledge, and the utilization of a transdisciplinary perspective. Though the wording and the utilization of certain tenets may vary across scholars and fields, the objectives of CRT are similar. According to Parker and Lynn (2002), the goals of CRT include the use of storytelling and narratives to re-examine racism in society, the elimination of racial subjugation while acknowledging racism as inherent in society, and the creation of essential connections between race and other areas of domination.

In reviewing pertinent literature surrounding the experience of BMSAs, we utilized Solórzano and Yosso's (2002) first four tenets as outlined below, while also incorporating the tenet of interest convergence (Delgado \& Stefancic, 2017). Solórzano and Yosso (2002) named the first tenet the intercentricity of race and racism with other forms of subordination, which has similarities to intersectionality (Crenshaw, 1989). Intersectionality examines the ways in which racism exists alongside other forms of oppression based on gender, class, and other identities, particularly centering the experiences of Black women (Crenshaw, 1989). The second tenet ensures CRT offers a challenge to dominant ideologies, which in education often comes in the form of claims of objectivity, race-neutral practices, meritocracy, equal opportunity, and colorblindness - precisely what CRT challenges and critiques (Solórzano \& Yosso, 2002). In addition to challenging these problematic claims, a commitment to social justice with the objectives of "the elimination of racism, sexism, and poverty and the empowering of subordinated minority groups" is evident in CRT (Solórzano \& Yosso, 2002, p. 26). One way that CRT scholars empower these marginalized groups is through the emphasis placed on their voice (Delgado \& Stefancic, 2017).

The centrality of experiential knowledge offers a rationale for centering marginalized voices. Also referred to as the "voice of color" tenet (Delgado \& Stefancic, 2017), experiential knowledge (Solórzano \& Yosso, 2002) allows scholars to challenge ahistoricism and examine society with expertise provided by the targeted population (Tate, 1997). Experiential knowledge and voice of color come in the form of counterstories. These counterstories offer "a method of telling the stories of those people whose experiences are not often told," which leads to exposing of and challenging the dominant narratives (Solórzano \& Yosso, 2002, p. 32). A form of counterstories comes through composite narratives, which are stories constructed by authors that are based on varying forms of data (e.g., existing literature, interviews, personal experience; Alemán \& Alemán, 2010; Espino, 2012; Solórzano \& Yosso, 2002).

In addition to these tenets offered by Solórzano and Yosso (2002), we include the notion of interest convergence. The premise behind this tenet critiques dominant powers by noting that the majority (or dominant power) will act in their (self) interests unless an alternative option greatly benefits them (Delgado \& Stefancic, 2017). Interest convergence presumes that if the dominant group supports policies in alignment with the interests of marginalized groups, it is done for self-interests that converge with those of the marginalized (Harper, 2009). As we reviewed the 
literature on BMSAs, these tenets became a lens to inform our scholarly arguments toward dismantling dominant ideologies that tend to take a deficit approach to BMSAs (i.e., seeing disparities or struggles as inherent to individuals and not a fault of systems/structures). At the heart of this paper is providing a counternarrative to the dominant perspective. Thus, we first offer a summary of the dominant perspective found in the literature.

\section{The Dominant Perspective on the Education of Black Male Student-Athletes}

Dominant perspectives place the source of BMSA experiences solely on the BMSAs themselves, resulting in a belief that BMSAs should be appreciative of the opportunities afforded to them (Osborne, 2014). Pervasive stereotypes, such as the Black "dumb jock," which holds that these students lack the drive and intelligence to succeed academically (Edwards, 1984), perpetuate the belief that many of these student-athletes would not be in college without athletics. The dumb jock stereotype portrays these athletes "as academically unqualified illegitimate students whose only interest is athletics, who expect and receive special treatment from professors and others" (Simons et al., 2007, p. 252). While this stereotype can be attributed to all student-athletes, race plays a significant role. Being sites of acculturation, schools perpetuate stereotypical views that label Black people as athletically superior, yet intellectually inferior compared to their white counterparts (Harrison et al., 2004). Statistics also place BMSA achievement not only lower than their white counterparts but also lower than other Black students on college campuses (Harper, 2018).

Since BMSAs represent the Black "dumb jock" stereotype, the dominant perspective proclaims they should be grateful for the opportunity to receive an education, which is seen as a priceless gift to these student-athletes (Horne, 2008; Johnson \& Acquaviva, 2012). Thus, when conversations about paying student-athletes arise, particularly revenue-generating athletes, people forget the reason for going to college: to receive an education (Coil, 2019). College athletics is seen as merely an avenue to earn a free education (Coil, 2019).

The university is a place that provides all students more than a classroom educational experience. In the case of student-athletes, they are benefitting from access to the best facilities, coaches, travel, nutrition, as well as social activities provided by the institution (Johnson \& Acquaviva, 2012). In a message to these student-athletes, Horne (2008) directed, "Don't stare a gift horse in the mouth. Just keep your mouth shut, study, and play" (para. 23). This troubling take is further perpetuated through prominent scholarship, such as Osborne (2014) calling the exploited student-athlete a "myth," with a primary focus on football and basketball, which are Black-dominated sports at the Division I level (NCAA, 2020c). In response to critics of the exploitative system, Osborne (2014) exclaimed, "These are the rules. If you don't like the rules, don't play!" (p. 151).

Although most of the literature does not take such an explicit dominant and deficit-oriented approach to BMSAs, there are still dominant themes in the litera- 
ture, particularly around academics. Below we highlight some of these themes using authors who write about the content (though do not take a dominant perspective) to showcase these themes in the literature.

\section{The Dominance of Athletic Identity over Academic Identity}

Within the literature on the development of student-athletes, there is a predominant focus on psychosocial identity as an athlete (Bimper, 2014; Harrison et al., 2011). Furthermore, athletic identity has been found to be more prominent in Black student-athletes in revenue-generating sports as opposed to their white counterparts (Bimper, 2014). Higher levels of athletic identity have predicted lower levels of academic achievement, and academic paths deemed less challenging (Bimper, 2014). While college athletics provides many benefits (e.g., scholarships for education, access to resources, and traveling opportunities), there is an aspect of college athletics that does a disservice to the Black student-athlete. The nature of college athletics creates a saliency of athletic identity that leads to lower academic achievement and separation of the academic identity (Bimper, 2014; Harrison et al., 2017; Singer, 2005, 2019; Steinfeldt et al., 2010). As athletic departments emphasize the athletic identity of the student-athlete, less time is allowed for developing their other identities, such as student or racial identity.

This disservice to BMSAs is rooted in interest convergence (Bell, 1995). The athletic department's interests, particularly at Division I HWIs, surround the BMSA performing well on the playing surface. Athletic departments may claim they are invested in the holistic development of the BMSA; however, their minimal efforts to support the student-athlete beyond keeping them academically eligible to play thereby represent the interests of the institution (Comeaux, 2013; Donnor, 2005). Although BMSAs are offered academic support, the perception has historically been that they were at their specific institution to focus on sport (Singer, 2019). An athletic department may appear to act in the interest of the BMSA by offering support services; however, the reality is that the emphasis on athletic identity accurately paints the picture that the interest of the athletic department has and continues to be on the production of BMSAs on the playing surface.

\section{Environmental Interactions Influencing Academic Achievement}

Interactions between the college environment and student characteristics influence the academic achievement of BMSAs (Harrison et al., 2006). These characteristics include high school GPA, the variable that most likely predicted college GPA, of which white student-athletes enter with higher scores than their Black counterparts (Comeaux \& Harrison, 2011; Harrison et al., 2006). The reasoning behind this can vary; however, access to resources plays a role in this phenomenon as Black student-athletes enter the college setting coming out of high schools lacking the academic resources compared to those schools where white student-athletes graduated (Harrison et al., 2006).

An essential aspect of the student-athlete's experience comes with their interac- 
tion with faculty. Despite the reality that BMSA athletic identity tends to overshadow academic identity, many of these athletes turn to faculty members who serve "the role of "intellectual coach" (Harrison et al., 2006, p. 277). Student-athletes see positive benefits with increased faculty interaction; however, white student-athletes benefit most concerning GPA (Comeaux, 2005; Comeaux \& Harrison, 2007).

From these studies alone, one can note that there are significant differences in the college environment for BMSAs, which directly impact academic outcomes. The NCAA has taken steps to monitor the student-athletes' success by introducing the GSR and the Academic Progression Rate (APR). The GSR monitors the six-year graduation rate (NCAA, 2019) while the APR examines the retention and eligibility of student-athletes each term (NCAA, 2020a). However, simply monitoring a student-athlete's six-year graduation rate and eligibility standards do not create a complete system of accountability. The lack of institutional accountability has led to numerous problems surrounding the academic success of these athletes.

The incorporation of the GSR and APR models further perpetuate these colorblind and race-neutral policies (Solórzano \& Yosso, 2002), which mitigate the importance of critically examining the racial gaps in the academic achievement of student-athletes (Lapchick et al., 2019). Additionally, the monitoring of academic success is grounded in essentialism (Delgado \& Stefancic, 2017), which is the "belief that all people perceived to be in a single group think, act, and believe the same things in the same ways" (Ladson-Billings, 2013, p. 47). Grouping all student-athletes in the APR without examining why disparities may occur perpetuates the narrative that all student-athletes are the same.

Another aspect of the college environment relating to BMSAs is the notion of institutional integrity, which refers to the relationship between an institution's stated commitments to behaviors regarding the intellectual and social development of their students (Daniels, 1987). Bimper and Harrison (2017) found that numerous athletic departments commit to academic excellence; however, practices that would improve the development of BMSAs (e.g., increasing Black academic support staff) are lacking (Singer, 2009). If institutions do not maintain an adequate level of integrity and accountability, the academic achievement and development of BMSAs will continue to suffer.

\section{Academic Clustering}

One issue the lack of accountability has created surrounding the education of BMSAs is the occurrence of academic clustering. Sanders and Hildenbrand (2010) noted that academic "clustering occurs when athletes join up with other athletes (often their own teammates) in a narrow selection of academic majors" (p. 214). Academic clustering is defined as $25 \%$ or more student-athletes in a specific major (Fountain \& Finley, 2011). While academic clustering occurs with most athletes participating in revenue-generating sports, some findings prove Black student-athletes face this reality at a higher rate than their white counterparts (Fountain \& Finley, 2009).

As previously noted, BMSAs are so consumed by athletics that they are unable to focus much attention on academic identity. One of the reasons for this occurrence is the encouragement of BMSAs into majors that they may have no desire to be in 
because certain majors allow the student-athlete to be available for their athletic requirements. Coaches require student-athletes to be at practice, lift weights, watch film, and recover all before placing importance on academics. Further implicating interest convergence, BMSAs being forced into specific majors illustrates the loss of autonomy on the part of the BMSA (Delgado \& Stefancic, 2017) as institutional actors identify and promote "easier" pathways for the student-athletes, but only because their interests (i.e., winning games) are being served. Intersectionality (Ladson-Billings, 2013) also comes into play when race and gender are considered, as tracking into academic clusters is most apparent among Black males (Fountain \& Finley, 2009; Sanders \& Hildenbrand, 2010).

Given the higher percentage of clustering among Black student-athletes than their white counterparts (Fountain \& Finley, 2009), we must examine potential sources of the clustering, which likely begins at recruitment. With empty promises being made to these Black student-athletes during recruitment, they get to campus expecting to explore the institution's diverse offerings of majors only to be limited to choosing between a few majors (if given a choice at all). Instead, BMSAs realize only a limited number of majors fit within their athletic schedule. Popular majors/ disciplines that student-athletes find themselves clustered into are general studies, communications, social sciences, sport management, and business management, to name a few (Fountain \& Finley, 2009). In their study, Fountain and Finley (2009) found that out of the 11 schools in the sample that 6 of them had over $75 \%$ of their Black student-athletes in one of two majors. Being clustered into a major such as general studies sets the BMSA up for a challenging transition after college as academic clustering contributes to income inequalities, and those inequalities are seen to be higher within the Black student-athlete population (Sanders \& Hildenbrand, 2010).

In reviewing major themes in the literature, the dominant perspective is apparent. Yet, it is essential to examine literature regarding the academic achievement of BMSAs through various lenses to understand this dynamic between education and exploitation better. As noted by Comeaux and Harrison (2011), "Failure to distinguish between these multiple influences on academic success has frequently led to assumptions about student-athletes that too often present them through a deficit lens" (p. 235). We now turn to highlight themes in the literature from a more critical perspective that points to the exploitation of BMSAs.

\section{The CRT Perspective on the Exploitation of Black Male Athletes}

Counter to a deficit perspective, more critical perspectives focus on environmental and structural sources of BMSA challenges. The college environment for the student-athlete is defined as encompassing everything that may attribute or impact their time on campus as it pertains to graduating (Harrison et al., 2006). When discussing the educational experiences of student-athletes, it is essential that researchers factor race into the equation. Cooper and Dougherty (2015) proclaimed that "race continues to serve as a mitigating factor in the quality of student athletes' educational experiences at postsecondary institutions" (p. 91). Racial identity has an indirect impact on GPA through other related factors (Bimper, 2014). The existence of ra- 
cialized populations in predominantly white spaces creates a unique environment for racialized people, in this case, BMSAs.

\section{Limiting Opportunity}

Singer (2005) highlighted two emerging themes in the experiences of BMSAs: the lack of opportunity and the notion of being treated differently. Considering HWIs, the exploitative nature of the athletic system takes advantage of the athletic ability of BMSAs while subsequently being a detriment to their other identities and development (Bimper, 2014; Hawkins, 2010; Singer, 2005). Bimper and Harrison (2011) noted that "race and sport have become inseparable," and while BMSAs are in this impressionable part of their lives, scholars cannot assume the athletes understand that they are operating in a system that has controlled their sense of identity (p. 284). Controlling BMSAs' development also relates to academic clustering previously discussed. When institutions constrain athletes to specific majors, they are negatively impacting their career development (Navarro, 2015).

Another factor influencing opportunity is the lack of Black individuals in leadership roles, both at the player and administrator levels (Singer, 2005). A perceived power dynamic existed where Black people had to prove themselves and impress white hegemony as they ultimately have the power to afford them opportunities. Unfortunately, this power dynamic does not seem to be changing. Just as Ladson-Billings (2013) emphasized that activists must find ways in which to align the interests of the hegemonic powers to those of oppressed groups to see change, so too must the Black population in collegiate athletics. This is because of the unfortunate reality that "interest convergence is about alignment, not altruism" (Ladson-Billings, 2013, p. 45).

\section{Differential Treatment}

The second theme from Singer (2005) regarding the experiences of BMSAs was differential treatment. The level of care shown to BMSAs by student-athlete support staff was dissimilar to their white counterparts (Singer, 2005). Additionally, Singer's participants described how numerous opportunities were given to white players when the same opportunities were virtually non-existent to them. These findings echo sentiments apparent in the literature and serve as a wake-up call for those involved with collegiate athletics. Differential treatment is a reality for BMSAs particularly given the racist nature of society and institutions.

The literature on BMSAs highlights the inherent nature of racism in society. This theme aligned with the CRT tenet emphasizing the ordinariness of race and racism (Delgado \& Stefancic, 2017; Ladson-Billings, 2013; Singer, 2005). Additionally, Bimper (2014) acknowledged the uniqueness of the experience of BMSAs in the context of race. Likewise, facing discrimination from multiple identities is a reality for many Black student-athletes (Steinfeldt et al., 2010). Acknowledging that racism and other forms of discrimination are apparent in the realm of college athletics is vital as it opens the door for future research to be conducted regarding the impact race has within various aspects of collegiate athletics.

In contrast to the dominant perspective, the CRT perspective on BMSAs sheds 
a different light on the experiences of this population. Student-athletes should not remain silent and allow for the maintenance of the status quo, such as Horne (2008) suggested. Instead, we understand that institutions of higher education, particularly HWIs, have taken advantage of BMSAs for far too long (Beamon, 2008; Cooper, 2019; Harper, 2018; Singer, 2019). To address this concern, as well as extend the work of Singer (2008), we constructed a composite narrative concerning BMSAs.

\section{Composite Narrative}

Composite narratives are useful tools utilized by critical race scholars to highlight counterstories of racially minoritized individuals (Alemán \& Alemán, 2010; Espino, 2012; Solórzano \& Yosso, 2002). Specifically, "authors create composite characters and place them in social, historical, and political situations to discuss racism, sexism, classism, and other forms of subordination" (Solórzano \& Yosso, 2002, p. 33). Of note, composite narratives are grounded in data of varying type. The narrative we present is built from a combination of existing literature related to BMSAs and experiential knowledge. Within the narrative, there are references to literature that speaks to a specific claim or action. The counterstory is also created from knowledge gained through lived, professional, and scholarly experiences of the authors. I, Jonathan Howe, identify as a Black man who researches and works closely with BMSAs. My experiences working in collegiate athletics and spending informal time advising and mentoring BMSAs helped construct the narrative. I, Marc Johnston-Guerrero, identify as a multiracial Asian American man who studies campus racial climate and identity development for Students of Color. My practical experiences as an academic advisor in TRIO programs also informed the narrative.

The narrative is drawn from the perspective of an athlete support professional (Jamal) who is also a Black male. Jamal is going into his fifth year in his role at Big State University Athletic Department. Prior to this role, Jamal was a standout student-athlete at Big State as he received academic all-American and conference honors as well as similar honors for his play on the football field. Jamal graduated with his master's degree before a brief stint in the NFL as an undrafted free agent before coming back to Big State. Throughout the narrative, which includes interactions with BMSAs, we illustrate the intricacies of the BMSA experience related to the discourse of being educated or exploited.

\section{A Counterstory from a Both/And Perspective}

Jamal woke up Monday morning with an unexpected level of energy toward the week ahead. As one of the only Black male athlete support service professionals at his HWI, Jamal knew the vital role he would play in the weeks ahead. Coming off a win against their biggest rival, the football team was looking ahead to finish off the season strong. Unfortunately, several of the athletes were on the verge of ineligibility and had appointments with Jamal this week for advising. Jamal wished he were not the only one the Black male football players felt connected to in his office (Council et 
al., 2015). In particular, he wished there were more faculty who engaged the students and held them to the same expectations of their white counterparts.

Jamal remembers reading a study by Harrison et al. (2006) that found "faculty who provided intellectual challenges and stimulation for their students, encouraged graduate school, and helped in achieving professional goals made a relatively strong contribution to student success" (p. 281). Unfortunately, most faculty take a deficit approach (i.e., focusing solely on students' problems, needs, and deficiencies) to working with the Black football players, despite many BMSAs embodying intelligence and a drive that leads to academic success (Cooper, 2016b). In fact, Jamal knew numerous BMSAs who were academically successful (Cooper, 2016b). When students discuss coursework out of class with faculty, they tend to have more negative academic achievement. This outcome was not necessarily a surprise since Harrison et al. (2006) also argued that "students generally tend to seek assistance with their study skills when they are not doing well academically" (p. 282).

Jamal wondered how he could encourage the faculty members to increase communication and mentorship to these student-athletes, especially Black student-athletes. He remembered Harrison et al. (2006) noting this must be done in response to the needs of the student-athletes (see also Cooper, 2016a). For example, in designing programs to create these relationships with the student-athletes, focus should be placed on understanding how the practices in play can impact the student-athlete's academic achievement (Harrison et al., 2006). In offering solutions to improve upon the Black student-athlete and faculty interactions, Harrison et al. (2006) posited the following:

Faculty should not necessarily treat student-athletes differently from traditional students. Rather, faculty should be cognizant of their role as mentor and use this role as an opportunity to cultivate in students the best that academics and sport offers: dedication, commitment, perseverance, and teamwork. (p. 282)

In his position as the sole Black male representative in the athletic academic support services office, Jamal understood the landscape regarding racial representation in higher education. He recalls numerous meetings with the Black student-athletes he advises where statements such as "none of my professors look like me" or "he (the professor) doesn't care about Black people" were commonplace. Jamal noticed that these student-athletes were reluctant to approach white faculty members. Continuing to think of solutions regarding faculty interaction, he remembered Comeaux and Harrison (2007) positing, "The college experiences of Black student athletes at predominantly white institutions are often times hindered as a result of feelings of social isolation, racial discrimination, limited support and lack of integration. Thus, Black student athletes may choose to spend as little time as possible with white faculty" (p. 208).

An idea then came to Jamal to try to increase the informal interaction between faculty and student-athletes. Comeaux and Harrison (2007) highlighted numerous ways to accomplish this goal, such as inviting faculty to attend practices and games, developing faculty mentoring programs, and inviting faculty to athletic banquets. 
Jamal made a note to mention this idea to the head football coach the next time they met.

Later in the day, a BMSA by the name of Malcolm stopped by Jamal's office to talk about something that has been on his mind lately. Malcolm exclaimed, "Why does it seem like everyone in the athletic department is benefitting from the work of the football team?" Clarifying his comments, Malcolm noted in his class discussion around the business of college sport he learned that the football and men's basketball teams essentially funded all of the other sports in the department (Gaston-Gayles et al., 2018; Harper, 2018; Hawkins, 2010; Van Rheenen, 2013). Jamal responded in a way that did little to quell the anger Malcolm exhibited, noting, "Well, that is because it is true. The work that you and your teammates are doing provides opportunities for other student-athletes to compete at the highest level." Malcolm processed this comment for a few moments and then became angered again. "Why are we supporting the women's golf team or rowing team?!" Not knowing how far to take the conversation, Jamal then provided a basic description of Title IX, noting that it affords equal opportunity and funding for women in sport at institutions receiving federal funding (Buzuvis \& Newhall, 2012).

In response, Malcolm questioned, "Yeah, that is good and all, but there aren't many Black women in those sports. If we are supporting other sports, why can't we support Black women equally?" Jamal then opened up the conversation with some of his thoughts about Title IX. He emphasized how Title IX has afforded more opportunity for women to compete in sport; however, white women have benefitted the most because the sports used to increase participation are sports that require a high social class position (McGovern, 2018; Pickett et al., 2012). While not explicitly mentioning the word "exploitation," Malcolm left the conversation knowing that BMSAs generate money for the university to support other sports while also perpetuating the exclusion of Black women (Pickett et al., 2012). Jamal apologized to Malcolm for not making him feel better about the situation; however, Malcolm was thankful for the conversation. He responded, "You always keep it real with me. I know that I can come to you to discuss these things."

It is now $1 \mathrm{PM}$, and Jamal just finished a quick lunch while trying to catch up on emails and is now preparing for an academic advising session with a freshman Black male basketball player (Kevin) in his first semester. During that meeting, Jamal asked the student what career path he intended to pursue. Kevin responded, "First and foremost, it has been my dream to play in the NBA, so I want to pursue that. However, I have always liked engineering, so if the league doesn't work out for me, I want to be an engineer." Jamal has heard this story before (Harrison et al., 2017). Several student-athletes, particularly Black student-athletes, have walked through his door enthusiastic about majoring in one of the top disciplines (and most competitive/selective) of the university. To the censure of Jamal, their coaches utilize the institution's most valuable majors as a recruiting tactic, even though Black student-athletes often enter the collegiate setting with less academic preparation than their white counterparts (Cooper, 2016a), making their pathway to such selective 
majors more difficult. For Jamal, this felt like another example of utilizing the promise of academics to exploit BMSAs.

Jamal never doubted the ability of his BMSA advisees; instead, he often questioned the transparency about the necessary steps to reach their goals. Therefore, he felt a responsibility to his advisees to speak truthfully and guide them through the process. In discussion with Kevin, Jamal explained, "It is great that you have your eyes on an engineering degree; however, it cannot be a back-up option. It is going to take the same amount of time and energy as you devote to your athletic feats." Kevin responded with a willingness to exert the same amount of energy to his academics. Jamal then went through a list of items for Kevin to take note of, including the times of class offerings. "Most of the pre-requisite courses for that major are offered in the afternoon, during practice, so you need to discuss this plan with your coach. Once you inform him, I recommend taking the four pre-requisites during the spring and summer semesters," Jamal advised. He continued by highlighting the need to maintain a 3.25 GPA for admission into the major.

Before providing these recommendations, Jamal understood the influence that coaches have on their athletes' time as well as the structuring of incentives for coaches, which leads to unnecessary time BMSAs spend committed to their sport as opposed to developing in other areas (Howe, 2020). Jamal noted, "I know you feel like there is minimal opportunity to make your own choices, and that you often have to defer to your coach; however, the first step to take in this situation is to open up a dialogue about your desire to pursue an engineering degree." Kevin, feeling unsure about the plan, stated, "That sounds like a lot of hard work. I don't know if this is for me anymore." Jamal encouraged Kevin but also discussed a range of majors for Kevin to examine while hitting home the point that future careers are not always dependent on specific majors. He finished the conversation by stating, "There are always easier routes; however, I will encourage you to pick the route that most interests you. I will never push you to declare a specific major because it is easier or allows you to spend more time focusing on basketball. I will advocate for you regardless of the decision you make. If you want to be an engineer, I am on your side."

After wrapping up his meeting with Kevin, Jamal - whose advising timeslots are usually full - noticed that he did not have any additional meetings on his calendar. Still bothered by some of the recurring themes of exploitation impacting the BMSA experience, Jamal remembered an article sent to him from the university's faculty athletic representative that he would now have time to read. The article by Cooper (2016a) introduced a framework to enhance the BMSA experience called Excellence Beyond Athletics (EBA). Narratives surrounding the BMSA should be less about the "deficit-laden attributions" and should instead be more focused on the academic underperformance of the BMSA as a byproduct of systemic issues surrounding the failure to prepare these Black males (Cooper, 2016a).

Jamal was intrigued by the article's explanation of the EBA framework, which employs an anti-deficit approach that focuses on the BMSA's strengths as a method of empowerment. It is comprised of six key components in this holistic development 
process for the BMSA: self-identity awareness, positive social engagement, active mentorship, academic achievement, career aspirations, and balanced time management (Cooper, 2016a). Of these six components, Jamal realized that he could play an immediate role in active mentorship, academic achievement, and career aspirations. The active mentorship aspect of EBA involves creating a faculty mentorship program for BMSAs (Cooper, 2016a), similar to Jamal's idea to increase faculty interaction. Subsequently, he knew that this mentorship needed to extend beyond faculty members and include athletic support staff as well (Gaston-Gayles et al., 2015; Harrison \& Martin, 2012). Jamal also made it a point to discuss with the athletes that they should form constellation networks of various mentors to serve different needs (Kelly \& Dixon, 2014; Martin et al., 2010).

After reading the article and reflecting on his experiences, Jamal realized there needs to be a bridge to strengthen the connection between academics and athletics. There needs to be academic support programs for these student-athletes that are university-wide, faculty using culturally relevant pedagogies, and potential reforms in the first-year student-athlete experience where they will be free from athletic commitments in order to better acclimate to campus (Comeaux \& Harrison, 2011; Cooper, 2016a). Additionally, Jamal noticed that he already enacted some of the strategies within the career aspirations component during his advising meetings with Malcolm and Kevin. He made it a point to allow the student-athletes he advises to explore various career paths while also giving them the freedom to choose their majors (Cooper, 2016a).

Within the career aspiration components, Cooper (2016a) discussed the importance of inviting former athletes and alumni who share similar racial and sociocultural backgrounds as BMSAs. Jamal, with an awareness of his former teammates and friends within athletics who have cultivated successful careers outside of sport, and current industry connections, began thinking of ways that he could bring in those who shared similar social identities and experiences as his current BMSAs on campus. In similar regard, Jamal sought to incorporate narratives outside his network from BMSAs who have successfully negotiated both their student and athlete roles. He noted that having an example such as Myron Rolle who was an outstanding football player, graduated early, attend Oxford on a Rhodes Scholarship, and is currently a doctor. Jamal figured that an exemplary story like this would set an example for BMSAs on how to manage multiple, sometimes conflicting roles (Harrison et al., 2010). After reading Cooper's (2016a) article, Jamal felt assured that he could use the EBA framework to both acknowledge the feelings of exploitation his students voiced and reframe their focus on academic success to be inclusive of athletic success.

\section{Discussion}

The above counterstory of just one day's work for a Black male professional within an athlete support service office reflects the realities that BMSAs may be receiving a college education, yet the feelings of being exploited cannot be denied. Faculty and staff interested in genuinely supporting the success of BMSAs need to better understand these dynamics. Based on our review of the literature through a 
CRT lens, we believe that being critical is necessary for exposing the deficit-laden discourse and practices that lead to feelings of being exploited. But being critical can only get us so far. We also need strategies to move our work forward that attempts to disrupt the structures and policies oppressing Black athletes toward their ultimate liberation. As outlined in the counterstory, Cooper's EBA framework offers such strategies. Here, we highlight the three additional elements not discussed in the counterstory: self-identity awareness, positive social engagement, and balanced time-management.

Self-identity awareness is put in place to counteract the overemphasis that is placed upon the BMSA's athletic identity (Bimper, 2014; Cooper, 2016a; Harrison et al., 2006). Self-identity awareness is often facilitated through race-related discussions, including focusing on racial microaggressions (Cooper, 2016a). Solórzano et al. (2000) defined racial microaggressions as "subtle insults (verbal, nonverbal, and/ or visual) directed toward people of color, often automatically or unconsciously" (p. 60) and emphasized the need to create counter-spaces as a response to the racial microaggressions Black students experienced on campus. Solórzano et al. (2000) posited "counter-spaces serve as sites where deficit notions of people of color can be challenged and where a positive collegiate racial climate can be established and maintained" (p. 70). These counter-spaces can be utilized to empower BMSAs and afford them the confidence to challenge exploitative situations through increased awareness of and meaning ascribed to their identities.

The next aspect of EBA is positive social engagement. Cooper (2016a) noted positive social engagement allows student-athletes the ability to find purpose outside of their athletic ability while giving these athletes a chance to create and foster relationships within the community. Key examples of this would be engagement with Black fraternities and religious-affiliated organizations. Gragg and Flowers (2014) found that fraternity involvement positively influenced BMSAs as it connected them with community service opportunities and allowed BMSAs to gain a sense of brotherhood away from their athletic team. Likewise, being engaged with religious organizations has also provided areas for growth outside of BMSAs' athletic role (Gragg \& Flowers, 2014).

The final element of the EBA framework is balanced time management, which aligns with a call to action for universities to enforce the 20-hour rule that the NCAA has put in place (Cooper, 2016a). This rule is supposed to limit the student-athlete's practice time to 20 hours per week. However, this is not the reality as some athletes can spend as much as 40 hours a week focused on their sport (Harrison \& Martin, 2012; New, 2015). These sentiments are shared by Porter (2019), as he argued that institutions have an obligation to assist this population with time management plans. While some athletes may still opt to spend more time developing their athletic skills, further enforcement of this rule will eliminate institutions from informally requiring athletes to devote extra time to their sport.

The examination of pertinent literature regarding the shaping of the BMSA experience highlighted many issues that could be mitigated with the implementation of strategic programming, such as the EBA approach recommended by Cooper (2016a). While there are proposed plans and recommendations for the improvement of BM- 
SAs' academic experiences, Gaston-Gayles et al. (2015) noted that there is not a one size fits all model for supporting BMSAs. However, they did argue that effective practices should be put in place that have been proven to improve the academic success of BMSAs. The following implications are discussed so that higher education institutions and collegiate athletic departments can act to remedy the disservice they have shown BMSAs.

A topic that has not received much attention is the entry points to college for BMSAs. While many BMSAs may come straight from high school, some may transfer from community colleges, often with the aspirations of playing professionally (Harper, 2009). Their aspirations for playing professionally are less significant than the fact that they may come into the four-year institution at varying academic levels, which further emphasizes the need for aspects of EBA to be implemented. For example, there is a need to support Black male transfer student-athletes during the transition, and there may be an opportunity to introduce a first-year transfer program. By implementing these recommendations, the institution will be reaching Black student-athletes and engaging them in purposeful dialogue while serving as a bridge to assist the transfer student-athlete with their adjustment.

Not only is the implementation of EBA recommendations necessary, but equally critical is looking at who is creating this narrative and working with the BMSAs. According to the National Association of Academic and Student-Athlete Development Professionals (N4A), the professional organization for athletic academic support staff, academic support staff within athletics are professionals who are "dedicated to the academic and personal development of student-athletes" that includes the commitment to "educate, prepare, and advocate for student-athletes through transition, retention, graduation, and beyond" (National Association of Collegiate Director of Athletics, 2018). It is essential that there is representation of Black males employed as members of the academic support staff within the athletic department (Council et al., 2015). Referencing CRT, these Black male academic advisors embody the counternarrative in opposition to the deficit-based narrative surrounding Black males and BMSAs (Council et al., 2015; Delgado \& Stefancic, 2017; Solórzano \& Yosso, 2002).

It is imperative that employees at higher education institutions be educated on serving diverse populations as the needs of these students may vary (Council et al., 2015). While improving the representation of Black male athletic academic advisors does not automatically lead to stronger relationships between the BMSAs and their advisors, "it increases the likelihood of shared experiences and a deeper understanding of the unique challenges faced by Black males," especially at HWIs (Council et al., 2015, p. 85). Additionally, more Black male academic advisors could diminish interest convergence occurring.

With the purposeful relationship building between BMSAs and Black male advisors, there is an increased likelihood of genuine care that will be displayed by the advisor as opposed to acting in their self-interest. However, it is also of importance to note that a limitation of interest convergence is primarily based on the notion that white people always act in their self-interest (Harper, 2009). Just as Harper (2009) 
noted, there are likely some white academic advisors who act in the interests of BMSAs. However, as the counterstory outlines, Black male academic advisors have a unique opportunity and should see themselves better represented in these roles, especially because of the inherent differences that Council et al. (2015) highlighted. Amid this reform, there lies a need for athletic academic advisors and higher education institutions to move from trying to maintain player eligibility (Comeaux, 2013), which perpetuates low expectations (Bimper, 2014; Bimper \& Harrison, 2011; Harrison et al., 2017). Unfortunately, Black males are underrepresented in athletic academic support services, which creates a need to recruit and retain these individuals who can appropriately work with BMSAs on campus (Council et al., 2015).

We also acknowledge that only having Black support staff is not the reality, particularly at HWIs. Thus, it is recommended that all athletic support personnel, regardless of race, pursue culturally relevant developmental opportunities. One specific example would be attending the annual Black Student-Athlete Summit, which is now expanding its reach by offering regional summits. A wealth of knowledge is shared concerning issues of the Black student-athlete grounded in research, which offers direct translation to practice. Additionally, many of their resources are readily available on their website (https://www.bsasummit.org/).

In addition to the need to increase Black male representation in academic advising positions, there is also a need to increase Black faculty across campus. Faculty guidance and relationships are critical, particularly to the benefit of Black student-athletes (Comeaux, 2005; Comeaux \& Harrison, 2007; Harrison et al., 2006). Similar to the reasons for increasing Black male academic advisors, increasing Black faculty members at HWIs is vital as same-race mentorship experiences can increase levels of inspiration and engagement (Davis, 2007). Additionally, Davis (2007) emphasized, "Sparse numbers of Black faculty within the professoriate suggests a need for both commitment towards cultivation, recruitment, and retention of tenure earning Black faculty" (p. 227). Thus, increasing the number of Black faculty on campuses has the potential to improve the experiences of BMSAs at HWIs. However, our call to increase Black representation across campus is not limited to faculty. We extend this push to increase Black representation throughout campus, including senior leadership, non-athletic academic advisors, and staff.

\section{Conclusion}

This paper examined the BMSA experience at HWIs from a critical lens. Analyzing the existing literature through a CRT framework allowed for the creation of a counterstory that highlights how the hegemonic powers (collegiate athletic departments and higher education institutions) continue to oppress and exploit Black male bodies. When thinking of interest convergence, one example was the funneling of BMSA into majors that allow increased time spent on sport, which ultimately benefits the athletic department. Additionally, intersectionality emerged as not only were Black bodies being oppressed and exploited through a racial lens, their loss of autonomy illustrated oppression from multiple identities as the athletic departments 
viewed the BMSA in a lower class (Smith, 2010).

In addition, this paper sought ways to dismantle the system that perpetuates the exploitation of BMSAs (Hawkins, 2010). One way to dismantle these structures is by generating counternarratives like the one shared here to challenge dominant ideologies surrounding BMSAs. These dominant ideologies highlight the achievement gap between Black student-athletes and white student-athletes but fail to critically examine the reasons why this may occur. More research highlighting the voices of BMSAs discussing their experiences is needed.

Overall, institutions of higher education and athletic departments should seek ways to implement the EBA approach on their respective campuses. However, it is often the structure of intercollegiate athletics that places the BMSA at a disadvantage as the university benefits financially off their athletic talent without investment into their development off the playing surface (Cooper, 2016a). In agreement with Cooper (2016a), "[T] he adoption of these Excellence Beyond Athletics approaches sends the message that Black male student-athletes' identities are valued beyond athletics" (p. 280). Thus, we argue that BMSAs can be both educated and exploited while utilizing the EBA approach to provide further options to center excellence in academics without being exploited. Moving forward, more attention should focus on understanding the unique position BMSAs find themselves in during college.

\section{References}

Alemán, E., \& Alemán, S. M. (2010). “Do Latin@ interests always have to 'converge' with white interests?": (Re)claiming racial realism and interest-convergence in critical race theory praxis. Race Ethnicity and Education, 13(1), 1-21. https://doi.org/10.1080/13613320903549644

Beamon, K. K. (2008). “Used goods”: Former African American college student-athletes' perception of exploitation by Division I universities. Journal of Negro Education, 77(4), 352-364.

Beamon, K. K. (2012). "I'm a baller": Athletic identity foreclosure among African-American former student-athletes. Journal of African American Studies, 16(2), 195-208. https://doi.org/10.1007/s12111-012-9211-8

Bell, D. A. (1995). Who's affraid of critical race theory? University of Illinois Law Review, 893-910. https://doi.org/10.1177/0011392109342205

Bimper Jr., A. Y. (2014). Game changers: The role athletic identity and racial identity play on academic performance. Journal of College Student Development, 55(8), 805-807. https://doi.org/10.1353/csd.2014.0078

Bimper Jr., A. Y., \& Harrison Jr., L. (2011). Meet me at the crossroads: African American athletic and racial identity. Quest, 63(3), 275-288.

Bimper Jr., A. Y., \& Harrison Jr., L. (2017). Are we committed to issues of race? Institutional integrity across intercollegiate athletics. International Review for the Sociology of Sport, 52(6), 675-692. https://doi.org/10.1177/1012690215616270

Buzuvis, E. E., \& Newhall, K. E. (2012). Equality beyond the three-part test: Ex- 
ploring and explaining the invisibility of Title IX's equal treatment requirement. Marquette Sports Law Review, 22(2), 427-460.

Coil, A. (2019, September 29). Opinion: Paying college athletes is not the answer. State Press.

Cokley, K. O. (2007). Critical issues in the measurement of ethnic and racial identity: A referendum on the state of the field. Journal of Counseling Psychology, 54(3), 224-234. https://doi.org/10.1037/0022-0167.54.3.224

Comeaux, E. (2005). Predictors of academic achievement among student-athletes in the revenue-producing sports of men's basketball and football. The Sport Journal, 8(3), 1-8.

Comeaux, E. (2013). Rethinking academic reform and encouraging organizational innovation: Implications for stakeholder management in college sports. Innovative Higher Education, 38(4), 281-293. https://doi.org/10.1007/s10755-0129240-1

Comeaux, E., \& Harrison, C. K. (2007). Faculty and male student athletes: Racial differences in the environmental predictors of academic achievement. Race Ethnicity and Education, 10(2), 199-214. https://doi.org/10.1080/13613320701330726

Comeaux, E., \& Harrison, C. K. (2011). A conceptual model of academic success for student-athletes. Educational Researcher, 40(5), 235-245. https://doi. org/10.3102/0013189X11415260

Cooper, J. N. (2016a). Excellence beyond athletics: Best practices for enhancing Black male student athletes' educational experiences and outcomes. Equity and Excellence in Education, 49(3), 267-283. https://doi.org/10.1080/10665684.20 16.1194097

Cooper, J. N. (2016b). 'Focus on the bigger picture:' an anti-deficit achievement examination of black male scholar athletes in science and engineering at a historically white university (HWU). whiteness and Education, 1(2), 109-124. https:// doi.org/10.1080/23793406.2016.1272627

Cooper, J. N. (2019). From exploitation back to empowerment: Black male holistic (under)development through sport and (mis)education. Peter Lang.

Cooper, J. N., \& Dougherty, S. (2015). Does race still matter?: A post Bowl Championship Series (BCS) era examination of student athletes' experiences at a Division I historically Black college/university (HBCU) and predominantly white institution (PWI). Journal of Issues in Intercollegiate Athletics, 8, 74-101.

Council, M. R., Robinson, L. S., Bennett, R. A., \& Moody, P. M. (2015). Black male academic support staff: Navigating the issues with black student-athletes. In R. Bennett III., S. R. Hodge, D. L. Graham, \& J. L. Moore III (Eds.), Black males and intercollegiate athletics: An exploration of problems and solutions (pp. 69-89). Emerald Group Publishing.

Crenshaw, K. W. (1989). Demarginalizing the intersection of race and sex: A Black feminist critique of antidiscrimination doctrine, feminist theory and antiracist politics. The University of Chicago Legal Forum, 1989, 139-168.

Daniels, O. C. B. (1987). Perceiving and nurturing the intellectual development of 
Black student-athletes: A case for institutional integrity. Western Journal of Black Studies, 11(4), 155-163.

Davis, D. J. (2007). Access to academe: The importance of mentoring to Black students. The Negro Educational Review, 58(3-4), 217-231.

Delgado, R., \& Stefancic, J. (2017). Critical race theory: An introduction (3rd ed.). New York University Press.

Donnor, J. K. (2005). Towards an interest-convergence in the education of African-American football student athletes in major college sports. Race Ethnicity and Education, 8(1), 45-67. https://doi.org/10.1080/1361332052000340999

Edwards, H. (1984). The Black "dumb jock": An American sports tragedy. College Board Review, 131, 8-13.

Espino, M. M. (2012). Seeking the "truth" in the stories we tell: The role of critical race epistemology in higher education research. The Review of Higher Education, 36(1S), 31-67. https://doi.org/10.1353/rhe.2012.0048

Fountain, J. J., \& Finley, P. S. (2009). Academic majors of upperclassmen football players in the Atlantic Coast Conference: An analysis of academic clustering comparing white and minority players. Journal of Issues in Intercollegiate Athletics, 2, 1-13.

Fountain, J. J., \& Finley, P. S. (2011). Academic clustering: A longitudinal analysis of a Division I football program. Journal of Issues in Intercollegiate Athletics, 4, 24-41.

Gaston-Gayles, J., Comeaux, E., Ofoegbu, E., \& Grummert, S. (2018). Neoliberal capitalism and racism in college athletics: Critical approaches for supporting student-athletes. New Directions for Student Services, 163, 11-21. https://doi. org/10.1002/ss.20266

Gaston-Gayles, J., Crandall, R. E., \& Jones Jr., C. R. (2015). Advising Black male student-athletes: Implications for academic support programs. In R. A. Bennett, S. R. Hodge, D. L. Graham, \& J. L. Moore III (Eds.), Black males and intercollegiate athletics: An exploration of problems and solutions (pp. 45-68). Emerald Group Publishing.

Gragg, D., \& Flowers, R. D. (2014). Factors that positively affect academic performance of African American football student athletes. Journal for the Study of Sports and Athletes in Education, 8(2), 77-98. https://doi.org/10.1179/1935739 714z.00000000020

Harper, S. R. (2009). Race, interest convergence, and transfer outcomes for Black male student athletes. New Directions for Community Colleges, 2009(147), 2937. https://doi.org/10.1002/cc.375

Harper, S. R. (2018). Black male student-athletes and racial inequities in NCAA Division I revenue-generating college sports: 2018 edition.

Harrison, C. K., Comeaux, E., \& Plecha, M. (2006). Faculty and male football and basketball players on university campuses: An empirical investigation of the "intellectual" as mentor to the student athlete. Research Quarterly for Exercise and Sport, 77(2), 277-284. https://doi.org/10.1080/02701367.2006.10599361

Harrison, C. K., Lawrence, S., Bukstein, S., Janson, N., \& Woodie, K. (2010). Myron 
Rolle's ESPN page 2 story. Journal for the Study of Sports and Athletes in Education, 4(3), 231-242. https://doi.org/10.1179/ssa.2010.4.3.231

Harrison, C. K., \& Martin, B. E. (2012). Academic advising, time management and the African American scholar-athlete. In T. Stoilov (Ed.), Time Mangement (pp. 89-106). InTech. https://doi.org/10.5772/32009

Harrison Jr., L., Azzarito, L., \& Burden, J. W. (2004). Perceptions of athletic superiority: A view from the other side. Race Ethnicity and Education, 7(2), 149-166. https://doi.org/10.1080/1361332042000234277

Harrison Jr., L., Bimper Jr., A. Y., Smith, M. P., \& Logan, A. D. (2017). The mis-education of the African American student-athlete. Kinesiology Review, 6(1), 60-69.

Harrison Jr., L., Sailes, G. A., Rotich, W. K., \& Bimper Jr., A. Y. (2011). Living the dream or awakening from the nightmare: Race and athletic identity. Race Ethnicity and Education, 14(1), 91-103. https://doi.org/10.1080/13613324.20 11.531982

Hawkins, B. J. (2010). The new plantation: Black athlete, college sports, and predominantly white NCAA institutions. Palgrave Macmillan. https://doi.org/10.1017/ CBO9781107415324.004

Horne, L. (2008, October 4). Why college football players should not get paid to play. Bleacher Report.

Howe, J. E. (2020). Manifestations of athletic identity in Black male collegiate student-athletes: Introduction of a model. Journal of Amateur Sport, 6(2), 107-135. https://doi.org/10.17161/jas.v6i2.13636

Johnson, D. A., \& Acquaviva, J. (2012). Point/counterpoint: Paying college athletes. Sport Journal, 15(1).

Kelly, D. D., \& Dixon, M. A. (2014). Successfully navigating life transitions among African American male student-athletes: A review and examination of constellation mentoring as a promising strategy. Journal of Sport Management, 28(5), 498-514.

Ladson-Billings, G. (2013). Critical race theory-What it is not! In M. Lynn \& A. D. Dixson (Eds.), Handbook of critical race theory in education (pp. 42-52). Routledge. https://doi.org/10.4324/9780203155721.ch3

Lapchick, R. E., Ariza, P., Ellis, C., Gladney, D., Hudson, I., Mali, M., Morrin, D., Mutebi, N., Vasquez, A., \& Zimmerman, D. (2019). Keeping score when it counts: Assessing the academic records of the 2019-2020 bowl-bound college football teams.

Lapchick, R. E., Bowman, D., Eichenberger, D., Ewing, S., Forbes, A. J., Green, A., Jackson, B., Johnson-Schmeltzer, B., Kiernan, A., Middleton, T., Miller, D., Richardson, K., \& Turner, A. (2021). The 2020 racial and gender report card.

Martin, B., Harrison, C. K., \& Bukstein, S. (2010). "It takes a village" for African American male scholar-athletes. Journal for the Study of Sports and Athletes in Education, 4(3), 277-295. https://doi.org/10.1179/ssa.2010.4.3.277

McGovern, J. (2018). "You have to have money to be good": How capital accumula- 
tion shapes Latinas' pathways to college sports. Journal of Intercollegiate Sport, 11(2), 149-171. https://doi.org/10.1123/jis.2018-0038

NACDA. (2018). About N4A. NACDA.Com. https://nacda.com/sports/2018/7/17/ nfoura-aboutus-html.aspx

Navarro, K. M. (2015). An examination of the alignment of student-athletes' undergraduate major choices and career field aspirations in life after sports. Journal of College Student Development, 56(4), 364-379. https://doi.org/10.1353/ csd.2015.0034

NCAA. (2019). How are NCAA graduation rates calculated?

NCAA. (2020a). Academic progress rates explained. NCAA.Org. http://www.ncaa. org/about/resources/research/academic-progress-rate-explained

NCAA. (2020b). Division I graduation rates database. NCAA.Org. http://www. ncaa.org/about/resources/research/division-i-graduation-rates-database

NCAA. (2020c). NCAA demographics database. NCAA.Org. http://www.ncaa.org/ about/resources/research/ncaa-demographics-database

New, J. (2015, May 8). What off-season? Inside Higher Ed.

Osborne, B. (2014). The myth of the exploited student-athlete. Journal of Intercollegiate Sport, 7(2), 143-152. https://doi.org/10.1123/jis.7.2.143

Parker, L., \& Lynn, M. (2002). What's race got to do with it? Critical race theory's conflicts with and connections to qualitative research methodology and epistemology. Qualitative Inquiry, 8(1), 7-22.

Pickett, M. W., Dawkins, M. P., \& Braddock, J. H. (2012). Race and gender equity in sports: Have white and African American females benefitted equally from Title IX? American Behavioral Scientist, 56(11), 1581-1603. https://doi. org/10.1177/0002764212458282

Porter, J. (2019). An examination of the experiences of Black football athletes. Journal of Intercollegiate Sport, 12(1), 73-102. https://doi.org/10.17161/jis. v12i1.11561

Sanders, J. P., \& Hildenbrand, K. (2010). Major concerns? A longitudinal analysis of student-athletes' academic majors in comparative perspective. Journal of Intercollegiate Sport, 3(2), 213-233. https://doi.org/10.1021/om010914+

Simons, H. D., Bosworth, C., Fujita, S., \& Jensen, M. (2007). The athlete stigma in higher education. College Student Journal, 41(2), 251-273.

Singer, J. N. (2005). Understanding racism through the eyes of African American male student-athletes. Race Ethnicity and Education, 8(4), 365-386. https://doi. org/10.1080/13613320500323963

Singer, J. N. (2008). Benefits and detriments of African American male athletes' participation in a big-time college football program. International Review for the Sociology of Sport, 43(4), 399-408. https://doi.org/10.1177/1012690208099874

Singer, J. N. (2009). African american football athletes' perspectives on institutional integrity in college sport. Research Quarterly for Exercise and Sport, 80(1), 102-116. https://doi.org/10.1080/02701367.2009.10599534

Singer, J. N. (2019). Race, sports, and education: Improving opportunities and out- 
comes for Black male college athletes. Harvard Education Press.

Smith, W. A. (2010). Toward an understanding of misandric microagressions and racial battle fatigue among African Americans in historically white institutions. In E. M. Zamani-Gallaher \& V. C. Polite (Eds.), The State of The African American Male (pp. 265-277). Michigan State University Press.

Solórzano, D. G., Ceja, M., \& Yosso, T. J. (2000). Critical race theory, racial microaggressions, and campus racial climate: The experiences of African American college students. Journal of Negro Education, 69(1), 60-73. https://doi. org/10.1080/095183998236926

Solórzano, D. G., \& Yosso, T. J. (2002). Critical race methodology: Counter-storytelling as an analytical framework for education research. Qualitative Inquiry, $8(1), 23-44$.

Steinfeldt, J. A., Reed, C., \& Steinfeldt, M. C. (2010). Racial and athletic identity of African American football players at historically Black colleges and universities and predominantly white institutions. Journal of Black Psychology, 36(1), 3-24. https://doi.org/10.1177/0095798409353894

Tate, W. F. (1997). Critical race theory and education: History, theory, and implications. Review of Research in Education, 22, 195-247.

Van Rheenen, D. (2013). Exploitation in college sports: Race, revenue, and educational reward. International Review for the Sociology of Sport, 48(5), 550-571. https://doi.org/10.1177/1012690212450218

\section{Endnotes}

1. We note that much scholarly work utilizes the terms African American or Black. Cokley (2007) made the distinction between the two terms when he noted that African American refers to one's ethnicity which is a group of people with shared history, ancestry, and cultural traits; while Black refers to one's race which is society's grouping of people based off shared physical and hereditary characteristics. While these terms are often used interchangeably, based off Cokley's (2007) distinction between the two terms and the presumption of CRT that race is a construct of society (Delgado \& Stefancic, 2017) we use the term Black throughout this paper as a way to avoid confusion for the reader. 